COGNitive STUdies | Études COGNitives, 12 SOW Publishing House, Warsaw 2012

VIOLETTA KOSESKA-TOSZEWA ${ }^{1, A}$, MAKSIM DUSZKIN $^{1, B}$

${ }^{1}$ Institute of Slavic Studies, Polish Academy of Sciences, Warsaw, Poland

${ }^{A}$ amaz@inetia.pl , ${ }^{B}$ demaksid@gmail.com

\title{
ABOUT MEANINGS AS A RULE NOT INCLUDED IN DICTIONARIES
}

\begin{abstract}
The article discusses the problem of ambiguity of the exponents of logical existential quantification occurring in the verbal group of Bulgarian, Polish and Russian sentences: Bulg. отвреме навреме, понякога, Pol. od czasu do czasu, czasem, czasami, Rus. время от времени, иногда. This ambiguity can be explained by strong and weak existential quantification. Lexical semantics did not distinguish between these two types of existentiality. Here we present a description of selected exponents of logical existential quantification in Bulgarian, Polish and Russian.

Keywords: Quantification, quantifier, existentiality, universality, uniqueness, strong and weak quantificational meaning, verbal group, semantic structure of the sentence, state, event.
\end{abstract}

The problem will be presented based on selected examples. Of course, it concerns more general issues connected with the contemporary understanding of language semantics, and is well worth attention.

1. As stated already in Volume 2 of Bulgarian-Polish contrastive grammar, and confirmed in its Volume 7 (Koseska, Gargov 1990), (Koseska 2006), the Polish expressions od czasu do czasu, czasem, czasami and the corresponding Bulgarian отвреме навреме, понлкога are expressions of existential quantification, and occur next to verbal forms in sentences with incomplete quantification in the verbal phrase. In Russian, their analogues are the expressions время от времени, иногда, временами ${ }^{1}$.

\footnotetext{
${ }^{1}$ In Russian dictionaries, these expressions are usually treated as unambiguous ones. As an aside, we can also note that in the dictionaries the said expressions are most often defined mutually through each other. For example, in „Русский семантический словарь” (editor: Švedova), иногда is defined as 'время от времени, иной раз' (RSS 1998, the иногда entry, p. 34), and время от времени - as 'иногда' (RSS 2003, the время entry, p. 45). Similarly also at Jefremova: иногда is an unambiguous lexem, meaning the same as 'время от времени, порой' (Jefremova 2000).
} 
1.1. Bulgarian expressions of the type: понлкога $P$, отвреме -навреме $P$ and the corresponding Polish expressions czasem $P$, czasami $P$, od czasu do czasu $P$, as well as Russian иногда $P$, временами $P$, время от времени $P$, have the contents which can be explicated using the existential quantifier, though the picture is much more complicated. Hence we will consider it in more detail.

1.2. In all the three Slavic languages discussed here, quantifying expressions can have different meanings within the same quantification: universal, existential, or unique. For example, the expressions of universality Bulg. винаги // Pol. zawsze // Rus. всегда have at least two meanings.

In the FIRST meaning, Bulg. винаги // Pol. zawsze // Rus. всегда can be explicated using the universality quantifier ranging over a sets of given cases (conditions).

For example: Bulg. Tой винаги сънува кошмари, i.e. винаги, когато спи, сънува кошмари // Pol. Jemu zawsze śnia się koszmary, i.e. Jemu, zawsze, kiedy śpi, śnią się koszmary // Rus. Ему всегда снятся кошмары, i.e. Ему всегда, когда он спит, снятся кошмары. Most generally, this meaning can be explicated as: „Always when A, then B." Here condition A specifies the set of cases (states) that are referred to in the sentence. Those cases need not be only states - they can also be events. (For the distinction between a state and an event, see (Mazurkiewicz 1986)).

In the SECOND meaning, the lexems Bulg. винаги // Pol. zawsze // Rus. всегда express universality, but within a given case, for example, within a given state. This meaning can be represented as the meaning of a ,continuous state state without breaks."

For example: Bulg. Той е бил винаги мбж на Мария // Pol. On zawsze byt mе̨zет Marii // Rus. Он всегда был мужем Марии, where the state мбж на Мария // те̨іет Marii // мужем Марии is unique, but the universality expressions Bulg. винаги // Pol. zawsze // Rus. всегда tell us that the state continues without any breaks.

In turn, the first meaning понякога // czasem (niekiedy) // иногда (изреджа) is analogous to the meaning of zawsze // винаги // всегда, when such zawsze // винаги $/ /$ всегда are quantifiers ranging over the set of appropriate cases (conditions). In this meaning, the expressions понякога // czasem, czasami // иногда are quantifiers ranging over the set of conditions (states) that are referred to in the sentence, e.g. Bulg. Tой понякога я сбнува // Pol. On śni czasem (czasami) о niej // Rus. Он иногда видит ее во сне, or: "Sometimes, when he sleeps, he sees her in his dreams."

This meaning of понякога // czasem, сzаsаті // иногда can be explicated as "It happens that when A, then B", where condition A specifies the set of appropriate cases. In this meaning, понякога // czasem, czasami // иногда have a meaning close to Bulg. поне един пбт, по някое време, в някои случаи, and - similarly as the Bulgarian exponent of universality винаги - never occur with the aorist of perfect verbs. However, we encounter it next to the forms of imperfectum and praesens of imperfect verbs. 
See the impossibility of building a Bulgarian sentence with понякога next to the aorist of perfect verbs, or * Той понякога отиде на работа. (See KoseskaToszewa, 1985: 195-201). The above semantic limitation is of the same character as the semantic limitations in the examples given by Padučeva: * Иван всегда глухой, * Kum всегда млекопитающее, according to whom Rus. всегда does not occur in the context of constant properties, i.e. in a situation without temporal localization. (See Padučeva, 1985: 226-227).

The second quantificational meaning of the expressions понякога // czasem, czasami // иногда is also existential, but within a given case, e.g. within a given state. Then it has the paraphrases "with breaks", "not all the time". In that case, понякога, similarly as Bulg. отвреме-навреме, Pol. od czasu do czasu, Rus. времл от времени, is a quantifying expression ranging over a multiplicity of states and events, e.g. Bulg. Той понякога (отвреме-навреме) беше добгр кбмм нея // Pol. On czasami (od czasu do czasu) bywat dobry dla niej // Rus. Oн иногда (время от времени) бывал к ней добр.

The quantifying expressions понякога // сzаsаті // иногда оссur in this meaning only when they can be replaced by the expressions: nie bez przerwy, z przerwami without changing the meaning of the sentence. In this meaning, понлкога / / czasami // иногда come close to the meaning of the expressions Bulg. отвреме-навреме, сегиз-тогиз, час по час // Pol. od сzаsи do сzаsи // Rus. время om времени, which have not only an existential quantificational meaning, but also posses a quantitative shade of meaning, connected with the signal of interruptability within a given state.

2. In the second volume of Bulgarian-Polish Contrastive Grammar, Violetta Koseska-Toszewa and Georgi Gargov proposed distinguishing the above differences in meaning within the same quantification with the labels of strong and weak quantificational meaning, singled out based on secondary semantic properties of expressions. We are of the opinion that this phenomenon is worth reminding about, among others, because of the various misunderstandings occurring at present in the so-called subject literature.

2.1. The strength of a quantificational meaning is determined by the position of the quantifier in the semantic structure of the sentence (Not to be mistaken for the formal structure of the sentence!)

If the quantifier has the broadest scope in the semantic structure of the sentence, i.e. if it encompasses with its scope all other quantifiers present in the semantic structure of the sentence, then we speak about a strong quantifying meaning.

If the position of the quantifier is within the scope of other quantifiers present in the semantic structure of the sentence, then the quantificational meaning is weak.

Hence in case of the sentence: Всички бяхме ангажсирани в една (някаква) работа, която ни отнемаше иялото време. // Wszyscy byliśmy zaangażowani w pewnej sprawie, która nam zabierała bardzo duż czasu. // Все мы были заняты одним делом, которое занимало у нас очень много времени. we have the following interpretation: "There is a certain object (some work!), for which it is true that for a unique set (we - us) there was a state in the past (byliśmy zaangażowani 
- we were engaged), and that for each of us it is true that he/she was engaged in the same object, i.e. the work was the same!"

The existential expression pewna praca // една работа // одно дело has the broadest scope of quantification in the semantic structure of the sentence, and encompasses with its scope all other quantifiers, i.e. the unique quantifier (us all) and the existential quantifier (there was a state of "being engaged"). The expression pewna praca // една работа // одно дело has a strong existential meaning.

However, in case of the sentence: Всички бяхме ангажирани в една (някоя) работа, която ни отнемаше иялото време // Wszyscy byliśmy zaangażowani $w$ (jakiejś) sprawie, zabierajacej nam bardzo duż czasu // Bсе мы были заняты (каким-либо) делом, занимающим у нас много времени., we have the following interpretation: "For a unique set (we - us), it is true that there was a state in the past (byliśmy zaangażowani - we were engaged), and that for each of us it is true that there was an object (here work!) that engaged us. However, that object (work) could have been different for all of us."

In this case, the expression: една работа - някоя работа // praca - jakaś praca // работа - какая-либо работа has a weak existential meaning, since it occurs within the scope of two quantifiers: the unique quantifier (us all) and the existential quantifier (there was a state of "being engaged").

In this case, the most important factor for the semantic structure of the sentence is the information about the work that we all performed. In the second - about the work performed by each of us. There is no doubt that the distinction between strong and weak quantifying meanings reflects in a precise way what cannot be reflected by the theory of the thematic - rhematic structure of the sentence.

The quantifying expressions понякога // czasem, czasami // иногда оссurring in the sentences Bulg. Той понякога я сгнува // Pol. On śni czasem (czasami) o niеj // Rus. Он иногда видит ее во сне have strong existential meanings ('Czasem, kiedy, śpi, widzi ją we śnie'). However, in the sentences Tой понякога (отвременавреме) беше добгр кгмм нея // Pol. On czasami (od czasu do czasu) bywat dobry dla niej // Rus. Он иногда (время от времени) бъвал к ней добр those expressions have weak existential meanings.

3. When the Bulg. понякога has a strong quantifying meaning, its Polish analogues are the expressions czasem, czasami, and the Russian analogue - the expression иногда.

If the Bulg. понякога has a weak existential quantifying meaning, its Bulgarian synonyms are отвреме-навреме, сегиз-тогиз, час по час, the Polish ones the expressions od czasu do czasu, czasami (only when czasami is equivalent with respect to meaning to the expression od czasu do czasu), and the Russian expression врем от времени.

The quantifying expressions отвреме-навреме // od czasu do сzаsи // время oт времени always have a weak existential quantificational meaning.

3.1. The expressions понякога // сzаsет, сzаsаті // иногда are ambiguous, and can have, depending on the context, both strong and weak existential quantificational meanings. 
Weak quantificational meanings are often a starting point for developing new quantificational meanings. In this case, the aim is to bring the meaning closer to a quantitative one, different from the scope-based meaning of the expression. See the use of the expression отвреме-навреме // od czasu do сzаsи // время от времени with the expressions много пгти // wiele razy // много раз. See also (KoseskaToszewa, Gargov, 1990) and the sentences: Някой звлр се промбква насам (weak existentiality), Трябва да утрепем някой звяр (weak universality), Собийският адвокат бе много хитгр (weak uniqueness) and Адвокатвт е хитро същество (weak universality).

3.2. Due to the absence of article and a smaller number of tenses, in Polish and Russian we have more sentences with a semantic structure characterized by incomplete quantification than in Bulgarian (compare Pol. Dziewczyna czeka, Rus. Девушка ждет - Some, Certain, This unique, or Every? with the Bulgarian Момичето чака, where Момичето 'girl' is either this unique one, or each.)

This fact shows the stronger role of Polish lexems like czasami, od czasu do czasu, сzasem, and Russian иногда, время от времени, in the semantic structure of the sentence compared to their Bulgarian analogues. In Polish and Russian such lexems are a very important, and often the only factor determining the scope and position of a quantifier in the semantic structure of the sentence.

3.3. The distribution of the expressions понякога, отвреме-навреме, сzаsет, czasami, od czasu do сzаsи, иногда, время от времени shows that we cannot talk about the meaning of selected lexems without analyzing the whole semantic structure of the sentence. This fact might perhaps be trivial, but it is still worth stressing, because sometimes linguistic semantics is - unfortunately — still understood as lexical semantics only. And both these fields of linguistic semantics should be married. We firmly believe that, together with development of contemporary linguistic semantics, the methodology used in lexical semantics will also changed — and as a consequence our ordinary and electronic dictionaries will be enriched.

\section{References}

Gargov 1987: G. Gargov, O pewnym zbiorze przysłówków temporalnych i kwantyfikatorach uogólnionych [In:] Studia gramatyczne bułgarsko-polskie, t. II Określoność/nieokreśloność, Ossolineum, Wrocław.

Jefremova 2000: Т. Ф. Ефремова, Новый словарь русского языка. Толково-словообразователъный, „Русский язык”, Москва.

Koseska-Toszewa 1981: V. Koseska-Toszewa, Predykacja imienna w języku bułgarskim $w$ zestawieniu z polskim [in:] Zagadnienia predykacji imiennej $\mathrm{w}$ językach południowosłowiańskich, Ossolineum, Wrocław: 8-10.

Koseska-Toszewa 1982: V. Koseska-Toszewa, Semantyczne aspekty kategorii określoności / nieokreśloności (na materiale z języka butgarskiego, polskiego i rosyjskiego), Ossolineum, Wrocław.

Koseska-Toszewa 1985: V. Koseska-Toszewa, Jak rozgraniczyć użycie aorystu od niedokonanych od użycia imperfectum od niedokonanych? SFPS, t. XXIII, Warszawa: 195-201. 
Koseska-Toszewa, Gargov 1990: В. Косеска-Тошева, Г. Гаргов, Българско-полска съпоставителна граматика, т. 2, Семантичната категория определеност/неопределеност, София, БАН.

Koseska-Toszewa, Maldžieva, Penčev 1996: V. Koseska-Toszewa, V. Maldžieva, J.Penčev, Gramatyka Konfrontatywna Bułgarsko-Polska, t.VI, Modalność. Problemy teoretyczne, SOW, Warszawa.

Koseska 2006: V. Koseska-Toszewa, Semantyczna kategoria czasu, Gramatyka Konfrontatywna Butgarsko-Polska, t. VII, SOW, Warszawa.

Mazurkiewicz 1986: A. Mazurkiewicz, Zdarzenia i stany: elementy temporalności [in:] Studia gramatyczne bułgarsko-polskie, t. I, Temporalność, Wrocław: 7-21.

Padučeva 1985: Е. Падучева, Высказывание и его соотнесенность с действительностью, Москва: 224-232.

Petri 1962: C. Petri, Fundamentals of the Theory of Asynchronous Information Flow, Proc. of IFIP' 62 Congress, North Holland Publ. Co., Amsterdam.

RSS 1998: Русский семантический словарь: толковый словарь, систематизированный по классам слов и значений, Российская академия наук. Ин-т рус. яз. им. В. В. Виноградова, Под общей ред. Н. Ю. Шведовой, т. 1, Слова указующие (местоимения). Слова именующие: имена существительные (Всё живое. Земля. Космос), “Азбуковник", Москва.

RSS 2003: Русский семантический словарь: толковый словарь, систематизированный по классам слов и значений, Российская академия наук. Ин-т рус. яз. им. В. В. Виноградова, Под общей ред. Н. Ю. Шведовой, т. 3, Имена существительные с абстрактным значением: Бытие. Материя, пространство, время. Связи, отношения, зависимости. Духовньй мир. Состояние природы, человека. Общество, "Азбуковник", Москва. 